JAMA. 2013 October 23; 310(16): 1721-1729. doi:10.1001/jama.2013.280318.

\title{
Conjunctivitis:
}

\section{A Systematic Review of Diagnosis and Treatment}

\author{
Amir A. Azari, MD and Neal P. Barney, MD \\ Department of Ophthalmology and Visual Sciences, University of Wisconsin, Madison.
}

\begin{abstract}
IMPORTANCE-Conjunctivitis is a common problem.

OBJECTIVE-To examine the diagnosis, management, and treatment of conjunctivitis, including various antibiotics and alternatives to antibiotic use in infectious conjunctivitis and use of antihistamines and mast cell stabilizers in allergic conjunctivitis.
\end{abstract}

EVIDENCE REVIEW-A search of the literature published through March 2013, using PubMed, the ISI Web of Knowledge database, and the Cochrane Library was performed. Eligible articles were selected after review of titles, abstracts, and references.

FINDINGS-Viral conjunctivitis is the most common overall cause of infectious conjunctivitis and usually does not require treatment; the signs and symptoms at presentation are variable. Bacterial conjunctivitis is the second most common cause of infectious conjunctivitis, with most uncomplicated cases resolving in 1 to 2 weeks. Mattering and adherence of the eyelids on waking, lack of itching, and absence of a history of conjunctivitis are the strongest factors associated with bacterial conjunctivitis. Topical antibiotics decrease the duration of bacterial conjunctivitis and allow earlier return to school or work. Conjunctivitis secondary to sexually transmitted diseases such as chlamydia and gonorrhea requires systemic treatment in addition to topical antibiotic therapy. Allergic conjunctivitis is encountered in up to $40 \%$ of the population, but only a small proportion of these individuals seek medical help; itching is the most consistent sign in allergic conjunctivitis, and treatment consists of topical antihistamines and mast cell inhibitors.

CONCLUSIONS AND RELEVANCE-The majority of cases in bacterial conjunctivitis are self-limiting and no treatment is necessary in uncomplicated cases. However, conjunctivitis caused by gonorrhea or chlamydia and conjunctivitis in contact lens wearers should be treated with antibiotics. Treatment for viral conjunctivitis is supportive. Treatment with antihistamines and mast cell stabilizers alleviates the symptoms of allergic conjunctivitis.

Conjunctiva is a thin, translucent membrane lining the anterior part of the sclera and inside of the eyelids. It has 2 parts, bulbar and palpebral. The bulbar portion begins at the edge of the cornea and covers the visible part of the sclera; the palpebral part lines the inside of the

Copyright 2013 American Medical Association. All rights reserved.

Corresponding Author: Amir A. Azari, MD, Department of Ophthalmology, Room F4/349, University of Wisconsin Madison, 600 Highland Ave, Madison, WI 53792 (amirazarimd@gmail.com)..

Conflict of Interest Disclosures: All authors have completed and submitted the ICMJE Form for Disclosure of Potential Conflicts of Interest and none were reported. 
eyelids (Figure 1). Inflammation or infection of the conjunctiva is known as conjunctivitis and is characterized by dilatation of the conjunctival vessels, resulting in hyperemia and edema of the conjunctiva, typically with associated discharge. ${ }^{1}$

Conjunctivitis affects many people and imposes economic and social burdens. It is estimated that acute conjunctivitis affects 6 million people annually in the United States. ${ }^{2}$ The cost of treating bacterial conjunctivitis alone was estimated to be $\$ 377$ million to $\$ 857$ million per year. ${ }^{3}$ Many US state health departments, irrespective of the underlying cause of conjunctivitis, require students to be treated with topical antibiotic eyedrops before returning to school. ${ }^{4}$

A majority of conjunctivitis patients are initially treated by primary care physicians rather than eye care professionals. Approximately $1 \%$ of all primary care office visits in the United States are related to conjunctivitis. ${ }^{5}$ Approximately $70 \%$ of all patients with acute conjunctivitis present to primary care and urgent care. ${ }^{6}$

The prevalence of conjunctivitis varies according to the underlying cause, which may be influenced by the patient's age, as well as the season of the year. Viral conjunctivitis is the most common cause of infectious conjunctivitis both overall and in the adult population ${ }^{7-13}$ and is more prevalent in summer. ${ }^{14}$ Bacterial conjunctivitis is the second most common cause $^{7-9,12,13}$ and is responsible for the majority $(50 \%-75 \%)$ of cases in children ${ }^{14}$; it is observed more frequently from December through April. ${ }^{14}$ Allergic conjunctivitis is the most frequent cause, affecting $15 \%$ to $40 \%$ of the population, ${ }^{15}$ and is observed more frequently in spring and summer. ${ }^{14}$

Conjunctivitis can be divided into infectious and noninfectious causes. Viruses and bacteria are the most common infectious causes. Noninfectious conjunctivitis includes allergic, toxic, and cicatricial conjunctivitis, as well as inflammation secondary to immune-mediated diseases and neoplastic processes. ${ }^{16}$ The disease can also be classified into acute, hyperacute, and chronic according to the mode of onset and the severity of the clinical response. ${ }^{17}$ Furthermore, it can be either primary or secondary to systemic diseases such as gonorrhea, chlamydia, graft-vs-host disease, and Reiter syndrome, in which case systemic treatment is warranted. ${ }^{16}$

It is important to differentiate conjunctivitis from other sight-threatening eye diseases that have similar clinical presentation and to make appropriate decisions about further testing, treatment, or referral. An algorithmic approach (Figure 2) using a focused ocular history along with a penlight eye examination may be helpful in diagnosis and treatment. Because conjunctivitis and many other ocular diseases can present as "red eye," the differential diagnosis of red eye and knowledge about the typical features of each disease in this category are important (Table 1).

\section{Methods}

The literature published through March 2013 was reviewed by searching PubMed, the ISI Web of Knowledge database, and the Cochrane Library. The following keywords were used: bacterial conjunctivitis, viral conjunctivitis, allergic conjunctivitis, treatment of bacterial 
conjunctivitis, and treatment of viral conjunctivitis. No language restriction was applied. Articles published between March 2003 and March 2013 were initially screened. After review of titles, abstracts, text, and references for the articles, more were identified and screened. Articles and meta-analyses that provided evidence-based information about the cause, management, and treatment of various types of conjunctivitis were selected. A total of 86 articles were included in this review. The first study ${ }^{8}$ was published in 1982 and the last ${ }^{19}$ in 2012. A level of evidence was assigned to the recommendations presented in Table 2 and Table 3 with the American Heart Association grading system: "The strongest weight of evidence (A) is assigned if there are multiple randomized trials with large numbers of patients. An intermediate weight (B) is assigned if there are a limited number of randomized trials with small numbers of patients, careful analyses of non-randomized studies, or observational registries. The lowest rank of evidence (C) is assigned when expert consensus is the primary basis for the recommendation. ${ }^{60}$

\section{How to Differentiate Conjunctivitis of Different Origins}

\section{History and Physical Examination}

Focused ocular examination and history are crucial for making appropriate decisions about the treatment and management of any eye condition, including conjunctivitis. Eye discharge type and ocular symptoms can be used to determine the cause of the conjunctivitis. ${ }^{61,62}$ For example, a purulent or mucopurulent discharge is often due to bacterial conjunctivitis (Figure 3A and Figure 3B), whereas a watery discharge is more characteristic of viral conjunctivitis (Figure $3 \mathrm{C}$ ) ${ }^{61,62}$; itching is also associated with allergic conjunctivitis. ${ }^{49,63}$

However, the clinical presentation is often nonspecific. Relying on the type of discharge and patient symptoms does not always lead to an accurate diagnosis. Furthermore, scientific evidence correlating conjunctivitis signs and symptoms with the underlying cause is often lacking. ${ }^{61}$ For example, in a study of patients with culture-positive bacterial conjunctivitis, $58 \%$ had itching, $65 \%$ had burning, and $35 \%$ had serous or no discharge at all, ${ }^{64}$ illustrating the nonspecificity of the signs and symptoms of this disease. In 2003, a large meta-analysis failed to find any clinical studies correlating the signs and symptoms of conjunctivitis with the underlying cause ${ }^{61}$; later, the same authors conducted a prospective study ${ }^{61}$ and found that a combination of 3 signs-bilateral mattering of the eyelids, lack of itching, and no history of conjunctivitis-strongly predicted bacterial conjunctivitis. Having both eyes matter and the lids adhere in the morning was a stronger predictor for positive bacterial culture result, and either itching or a previous episode of conjunctivitis made a positive bacterial culture result less likely. ${ }^{64}$ In addition, type of discharge (purulent, mucus, or watery) or other symptoms were not specific to any particular class of conjunctivitis. ${ }^{64,65}$

Although in the primary care setting an ocular examination is often limited because of lack of a slitlamp, useful information may be obtained with a simple penlight. The eye examination should focus on the assessment of the visual acuity, type of discharge, cor-neal opacity, shape and size of the pupil, eyelid swelling, and presence of proptosis. 


\section{Laboratory Investigations}

Obtaining conjunctival cultures is generally reserved for cases of suspected infectious neonatal conjunctivitis, recurrent conjunctivitis, conjunctivitis recalcitrant to therapy, conjunctivitis presenting with severe purulent discharge, and cases suspicious for gonococcal or chlamydial infection. ${ }^{16}$

In-office rapid antigen testing is available for adenoviruses and has $89 \%$ sensitivity and up to $94 \%$ specificity. ${ }^{66}$ This test can identify the viral causes of conjunctivitis and prevent unnecessary antibiotic use. Thirty-six percent of conjunctivitis cases are due to adenoviruses, and one study estimated that in-office rapid antigen testing could prevent 1.1 million cases of inappropriate treatment with antibiotics, potentially saving \$429 million annually. $^{2}$

\section{Infectious Conjunctivitis}

\section{Viral Conjunctivitis}

Epidemiology, Cause, and Presentation-Viruses cause up to $80 \%$ of all cases of acute conjunctivitis. ${ }^{8-13,67}$ The rate of clinical accuracy in diagnosing viral conjunctivitis is less than $50 \%$ compared with laboratory confirmation. ${ }^{49}$ Many cases are misdiagnosed as bacterial conjunctivitis. ${ }^{49}$

Between $65 \%$ and $90 \%$ of cases of viral conjunctivitis are caused by adenoviruses, ${ }^{49}$ and they produce 2 of the common clinical entities associated with viral conjunctivitis, pharyngoconjunctival fever and epidemic keratoconjunctivitis. ${ }^{62}$ Pharyngoconjunctival fever is characterized by abrupt onset of high fever, pharyngitis, and bilateral conjunctivitis, and by periauricular lymph node enlargement, whereas epidemic keratoconjunctivitis is more severe and presents with watery discharge, hyperemia, chemosis, and ipsilateral lymphadenopathy ${ }^{68}$ Lymphadenopathy is observed in up to 50\% of viral conjunctivitis cases and is more prevalent in viral conjunctivitis compared with bacterial conjunctivitis. ${ }^{49}$

Prevention and Treatment-Viral conjunctivitis secondary to adenoviruses is highly contagious, and the risk of transmission has been estimated to be $10 \%$ to $50 \%{ }^{6,14}$ The virus spreads through direct contact via contaminated fingers, medical instruments, swimming pool water, or personal items; in one study, $46 \%$ of infected people had positive cultures grown from swabs of their hands. ${ }^{69}$ Because of the high rates of transmission, hand washing, strict instrument disinfection, and isolation of the infected patients from the rest of the clinic has been advocated. ${ }^{70}$ Incubation and communicability are estimated to be 5 to 12 days and 10 to 14 days, respectively. ${ }^{14}$

Although no effective treatment exists, artificial tears, topical antihistamines, or cold compresses may be useful in alleviating some of the symptoms (Table 2). ${ }^{16,50}$ Available antiviral medications are not useful ${ }^{16,50}$ and topical antibiotics are not indicated. ${ }^{18}$ Topical antibiotics do not protect against secondary infections, and their use may complicate the clinical presentation by causing allergy and toxicity, leading to delay in diagnosis of other possible ocular diseases. ${ }^{49}$ Use of antibiotic eyedrops can increase the risk of spreading the infection to the other eye from contaminated droppers. ${ }^{49}$ Increased resistance is also of 
concern with frequent use of antibiotics. ${ }^{6}$ Patients should be referred to an ophthalmologist if symptoms do not resolve after 7 to 10 days because of the risk of complications. ${ }^{1}$

\section{Herpes Conjunctivitis}

Herpes simplex virus comprises $1.3 \%$ to $4.8 \%$ of all cases of acute conjunctivitis. ${ }^{9-12}$ Conjunctivitis caused by the virus is usually unilateral. The discharge is thin and watery, and accompanying vesicular eyelid lesions may be present. Topical and oral antivirals are recommended (Table 2) to shorten the course of the disease. ${ }^{16}$ Topical corticosteroids should be avoided because they potentiate the virus and may cause harm. ${ }^{16,71}$

Herpes zoster virus, responsible for shingles, can involve ocular tissue, especially if the first and second branches of the trigeminal nerve are involved. Eyelids (45.8\%) are the most common site of ocular involvement, followed by the conjunctiva $(41.1 \%) .{ }^{72}$ Corneal complication and uveitis may be present in $38.2 \%$ and $19.1 \%$ of cases, respectively. ${ }^{72}$ Patients with suspected eyelid or eye involvement or those presenting with Hutchinson sign (vesicles at the tip of the nose, which has high correlations with corneal involvement) should be referred for a thorough ophthalmic evaluation. Treatment usually consists of a combination of oral antivirals and topical steroids. ${ }^{73}$

\section{Bacterial Conjunctivitis}

Epidemiology, Cause, and Presentation-The incidence of bacterial conjunctivitis was estimated to be 135 in 10000 in one study. ${ }^{3}$ Bacterial conjunctivitis can be contracted directly from infected individuals or can result from abnormal proliferation of the native conjunctival flora. ${ }^{17}$ Contaminated fingers,,${ }^{14}$ oculogenital spread, ${ }^{16}$ and contaminated fomites ${ }^{48}$ are common routes of transmission. In addition, certain conditions such as compromised tear production, disruption of the natural epithelial barrier, abnormality of adnexal structures, trauma, and immunosup-pressed status predispose to bacterial conjunctivitis. ${ }^{16}$ The most common pathogens for bacterial conjunctivitis in adults are staphylococcal species, followed by Streptococcus pneumoniae and Haemophilus influenzae. ${ }^{41}$ In children, the disease is often caused by $H$ influenzae, $S$ pneumoniae, and Moraxella catarrhalis. ${ }^{41}$ The course of the disease usually lasts 7 to 10 days (Figure 3). ${ }^{62}$

Hyperacute bacterial conjunctivitis presents with a severe copious purulent discharge and decreased vision (Figure 3). There is often accompanying eyelid swelling, eye pain on palpation, and preauricular adenopathy. It is often caused by Neisseria gonorrhoeae and carries a high risk for corneal involvement and subsequent corneal perforation. ${ }^{17}$ Treatment for hyperacute conjunctivitis secondary to $N$ gonorrhoeae consists of intramuscular ceftriaxone, and concurrent chlamydial infection should be managed accordingly. ${ }^{47}$

Chronic bacterial conjunctivitis is used to describe any conjunctivitis lasting more than 4 weeks, with Staphylococcus aureus, Moraxellalacunata, and enteric bacteria being the most common causes in this setting ${ }^{62}$; ophthalmologic consultation should be sought for management.

Signs and symptoms include red eye, purulent or mucopurulent discharge, and chemosis (Figure 3). ${ }^{17}$ The period of incubation and communicability is estimated to be 1 to 7 days 
and 2 to 7 days, respectively. ${ }^{14}$ Bilateral mattering of the eyelids and adherence of the eyelids, lack of itching, and no history of conjunctivitis are strong positive predictors of bacterial conjunctivitis. ${ }^{64}$ Severe purulent discharge should always be cultured and gonococcal conjunctivitis should be considered (Figure $3 \mathrm{~B}$ ). ${ }^{16}$ Conjunctivitis not responding to standard antibiotic therapy in sexually active patients warrants a chlamydial evaluation. ${ }^{18}$ The possibility of bacterial keratitis is high in contact lens wearers, who should be treated with topical antibiotics ${ }^{14}$ and referred to an ophthalmologist. A patient wearing contact lenses should be asked to immediately remove them. ${ }^{65}$

Use of Antibiotics in Bacterial Conjunctivitis-At least $60 \%$ of cases of suspected or culture-proven acute bacterial conjunctivitis are self-limiting within 1 to 2 weeks of presentation. ${ }^{14}$ Although topical antibiotics reduce the duration of the disease, no differences have been observed in outcomes between treatment and placebo groups. In a large meta-analysis, ${ }^{19}$ consisting of a review of 3673 patients in 11 randomized clinical trials, there was an approximately $10 \%$ increase in the rate of clinical improvement compared with that for placebo for patients who received either 2 to 5 days or 6 to 10 days of antibiotic treatment compared with the placebo. No serious sight-threatening out comes were reported in any of the placebo groups. ${ }^{74}$ Some highly virulent bacteria, such as $S$ pneumoniae, $N$ gonorrhoeae, and $H$ influenzae, can penetrate an intact host defense more easily and cause more serious damage. ${ }^{17}$

Topical antibiotics seem to be more effective in patients who have positive bacterial culture results. In a large systemic review, they were found to be effective at increasing both the clinical and micro-biological cure rate in the group of patients with culture-proven bacterial conjunctivitis, whereas only an improved microbial cure rate was observed in the group of patients with clinically suspected bacterial conjunctivitis. ${ }^{67}$ Other studies found no significant difference in clinical cure rate when the frequencies of the administered antibiotics were slightly changed. ${ }^{41,75}$

Choices of Antibiotics: All broad-spectrum antibiotic eyedrops seem in general to be effective in treating bacterial conjunctivitis. There are no significant differences in achieving clinical cure between any of the broad-spectrum topical antibiotics. Factors that influence antibiotic choice are local availability, patient allergies, resistance pat terns, and cost. Initial therapy for acute nonsevere bacterial conjunctivitis is listed in Table 2.

Alternatives to Immediate Antibiotic Therapy: To our knowledge, no studies have been conducted to evaluate the efficacy of ocular decongestant, topical saline, or warm compresses for treating bacterial conjunctivitis. ${ }^{41}$ Topical steroids should be avoided because of the risk of potentially prolonging the course of the disease and potentiating the infection. ${ }^{16}$

\section{Summary of Recommendations for Managing Bacterial Conjunctivitis-In}

conclusion, benefits of antibiotic treatment include quicker recovery, decrease in transmissibility, ${ }^{49}$ and early return to school. ${ }^{4}$ Simultaneously, adverse effects are absent if antibiotics are not used in uncomplicated cases of bacterial conjunctivitis. Therefore, no treatment, a wait-and-see policy, and immediate treatment all appear to be reasonable 
approaches in cases of uncomplicated conjunctivitis. Antibiotic therapy should be considered in cases of purulent or mucopurulent conjunctivitis and for patients who have distinct discomfort, who wear contact lenses, ${ }^{14,18}$ who are immunocompromised, and who have suspected chlamydial and gonococcal conjunctivitis.

\section{Special Topics in Bacterial Conjunctivitis}

Methicillin-Resistant S aureus Conjunctivitis-It is estimated that 3\% to $64 \%$ of ocular staphylococcal infections are due to methicillin-resistant $S$ aureus conjunctivitis; this condition is becoming more common and the organisms are resistant to many antibiotics. ${ }^{76}$ Patients with suspected cases need to be referred to an ophthalmologist and treated with fortified vancomycin. ${ }^{77}$

Chlamydial Conjunctivitis-It is estimated that $1.8 \%$ to $5.6 \%$ of all acute conjunctivitis is caused by chlamydia,, $5-11$ and the majority of cases are unilateral and have concurrent genital infection. ${ }^{1}$ Conjunctival hyperemia, mucopurulent discharge, and lymphoid follicle formation $^{51}$ are hallmarks of this condition. Discharge is often purulent or mucopurulent. ${ }^{18}$ How ever, patients more often present with mild symptoms for weeks to months. Up to $54 \%$ of men and $74 \%$ of women have concurrent genital chlamydial infection. ${ }^{78}$ The disease is often acquired via oculogenital spread or other intimate contact with infected individuals; in newborns the eyes can be infected after vaginal delivery by infected mothers. ${ }^{16}$ Treatment with systemic antibiotics such as oral azithromycin and doxycycline is efficacious (Table 2); patients and their sexual partners must be treated and a coinfection with gonorrhea must be investigated. No data support the use of topical antibiotic therapy in addition to systemic treatment. ${ }^{16}$ Infants with chlamydial conjunctivitis require systemic therapy because more than $50 \%$ can have concurrent lung, nasopharynx, and genital tract infection. ${ }^{16}$

Gonococcal Conjunctivitis-Conjunctivitis caused by $N$ gonorrhoeae is a frequent source of hyperacute conjunctivas in neonates and sexually active adults and young adolescents. ${ }^{17}$ Treatment consists of both topical and oral antibiotics. Neisseria gonorrhoeae is associated with a high risk of cor-neal perforation. ${ }^{65}$

Conjunctivitis Secondary to Trachoma-Trachoma is caused by Chlamydia trachomatis subtypes A through $\mathrm{C}$ and is the leading cause of blindness, affecting 40 million people worldwide in areas with poor hygiene. ${ }^{79,80}$ Mucopurulent discharge and ocular discomfort may be the presenting signs and symptoms in this condition. Late complications such as scarring of the eyelid, conjunctiva, and cornea may lead to loss of vision. Treatment with a single dose of oral azithromycin $(20 \mathrm{mg} / \mathrm{kg})$ is effective. Patients may also be treated with topical antibiotic ointments for 6 weeks (ie, tetracycline or erythromycin). Systemic antibiotics other than azithromycin, such as tetracycline or erythromycin for 3 weeks, may be used alternatively. ${ }^{79,80}$ 


\section{Noninfectious Conjunctivitis}

\section{Allergic Conjunctivitis}

Prevalence and Cause-Allergic conjunctivitis is the inflammatory response of the conjunctiva to allergens such as pollen, animal dander, and other environmental antigens ${ }^{15}$ and affects up to $40 \%$ of the population in the United States ${ }^{15}$; only about $10 \%$ of individuals with allergic conjunctivitis seek medical attention, and the entity is often underdiagnosed. ${ }^{81}$ Redness and itching are the most consistent symptoms. ${ }^{15}$ Seasonal allergic conjunctivitis comprises $90 \%$ of all allergic conjunctivitis in the United States. ${ }^{82}$

Treatment-Treatment consists of avoidance of the offending antigen ${ }^{52}$ and use of saline solution or artificial tears to physically dilute and remove the allergens. ${ }^{15}$ Topical decongestants, antihistamines, ${ }^{52}$ mast cell stabilizers, ${ }^{52}$ nonsteroidal anti-inflammatory drugs, ${ }^{53,54}$ and corticosteroids ${ }^{82}$ may be indicated. In a large systemic review, both antihistamines and mast cell stabilizers were superior to placebo in reducing the symptoms of allergic conjunctivitis; researchers also found that antihistamines were superior to mast cell stabilizers in providing short-term benefits. ${ }^{52}$ Long-term use of the antihistamine antazoline and the vasoconstrictor naphazoline should be avoided because they both can cause rebound hyperemia. ${ }^{52}$ Steroids should be used with caution and judiciously. Topical steroids are associated with formation of cataract and can cause an increase in eye pressure, leading to glaucoma.

\section{Drug-, Chemical-, and Toxin-Induced Conjunctivitis}

A variety of topical medications such as antibiotic eyedrops, topical antiviral medications, and lubricating eyedrops can induce allergic conjunctival responses largely because of the presence of benzalkonium chloride in eye drop preparations. ${ }^{83}$ Cessation of receiving the offending agent leads to resolution of symptoms. ${ }^{16}$

\section{Systemic Diseases Associated With Conjunctivitis}

A variety of systemic diseases, including mucous membrane pemphigoid, Sjögren syndrome, Kawasaki disease, ${ }^{84}$ Stevens-Johnson syndrome, ${ }^{85}$ and carotid cavernous fistula, ${ }^{86}$ can present with signs and symptoms of conjunctivitis, such as conjunctival redness and discharge. Therefore, the above causes should be considered in patients presenting with conjunctivitis. For example, patients with low-grade carotid cavernous fistula can present with chronic conjunctivitis recalcitrant to medical therapy, which, if left untreated, can lead to death.

\section{Ominous Signs}

As recommended by the American Academy of Ophthalmology, ${ }^{16}$ patients with conjunctivitis who are evaluated by nonophthalmologist health care practitioners should be referred promptly to an ophthalmologist if any of the following develops: visual loss, moderate or severe pain, severe purulent discharge, corneal involvement, conjunctival scarring, lack of response to therapy, recurrent episodes of conjunctivitis, or history of herpes simplex virus eye disease. In addition, the following patients should be considered 
for referral: contact lens wearers, patients requiring steroids, and those with photophobia.

Patients should be referred to an ophthalmologist if there is no improvement after 1 week. ${ }^{1}$

\section{Importance of Not Using Antibiotic/Steroid Combination Drops}

Steroid drops or combination drops containing steroids should not be used routinely. Steroids can increase the latency of the adeno-viruses, the refore prolonging the course of viral conjunctivitis. In addition, if an undiagnosed corneal ulcer secondary to herpes, bacteria, or fungus is present, steroids can worsen the condition, leading to corneal melt and blindness.

\section{Conclusions}

Approximately $1 \%$ of all patient visits to a primary care clinician are conjunctivitis related, and the estimated cost of the bacterial conjunctivitis alone is $\$ 377$ million to $\$ 857$ million annually. ${ }^{3,5}$ Relying on the signs and symptoms often leads to an inaccurate diagnosis. Nonherpetic viral conjunctivitis followed by bacterial conjunctivitis is the most common cause for infectious conjunctivitis. ${ }^{7-13}$ Allergic conjunctivitis affects nearly $40 \%$ of the population, but only a small proportion seeks medical care. ${ }^{15,81}$ The majority of viral conjunctivitis cases are due to adenovirus. ${ }^{49}$ There is no role for the use of topical antibiotics in viral conjunctivitis, and they should be avoided because of adverse treatment effects. ${ }^{6,49}$ Using a rapid antigen test to diagnose viral conjunctivitis and avoid inappropriate use of antibiotics is an appropriate strategy. ${ }^{66}$ Bacterial pathogens are isolated in only $50 \%$ of cases of suspected conjunctivitis, ${ }^{18}$ and at least $60 \%$ of bacterial conjunctivitis (clinically suspected or culture proven) is self-limited without treatment. ${ }^{14}$ Cultures are useful in cases that do not respond to therapy, cases of hyperacute conjunctivitis, and suspected chlamydial conjunctivitis. ${ }^{16}$ Treatment with topical antibiotics is usually recommended for contact lens wearers, those with mucopurulent discharge and eye pain, suspected cases of chlamydial and gonococcal conjunctivitis, and patients with preexisting ocular surface disease. ${ }^{14,18}$ The advantages of antibiotic use include early resolution of the disease, ${ }^{19}$ early return to work or school, ${ }^{4,14}$ and the possibility of decreased complications from conjunctivitis. ${ }^{14}$ The majority of cases of allergic conjunctivitis are due to seasonal allergies. ${ }^{82}$ Antihistamines, mast cell inhibitors, and topical steroids (in selected cases) are indicated for treating allergic conjunctivitis. ${ }^{82}$ Steroids must be used judiciously and only after a thorough ophthalmologic examination has been performed to rule out her petic infection or corneal involvement, both of which can worsen with steroids. ${ }^{16,71}$

Physicians must be vigilant to not overlook sight-threatening conditions with similarities to conjunctivitis, as summarized in Table 1.

\section{Acknowledgments}

Funding/Support: This work was supported by National Institutes of Health (NIH) grant P30-EY016665 (Core Grant for Vision Research) and an unrestricted department award from Research to Prevent Blindness. The project was also supported by the Clinical and Translational Science Award program through the NIH National Center for Advancing Translational Sciences, grant UL1TR000427. 
Role of the Sponsor: The sponsors played no role in the design and conduct of the study; collection, management, analysis, and interpretation of the data; preparation, review, or approval of the manuscript; and decision to submit the manuscript for publication.

\section{REFERENCES}

1. Leibowitz HM. The red eye. N Engl J Med. 2000; 343(5):345-351. [PubMed: 10922425]

2. Udeh BL, Schneider JE, Ohsfeldt RL. Cost effectiveness of a point-of-care test for adenoviral conjunctivitis. Am J Med Sci. 2008; 336(3):254-264. [PubMed: 18794621]

3. Smith AF, Waycaster C. Estimate of the direct and indirect annual cost of bacterial conjunctivitis in the United States. BMC Ophthalmol. 2009; 9:13. [PubMed: 19939250]

4. Ohnsman CM. Exclusion of students with conjunctivitis from school: policies of state departments of health. J Pediatr Ophthalmol Strabismus. 2007; 44(2):101-105. [PubMed: 17410961]

5. Shields T, Sloane PD. A comparison of eye problems in primary care and ophthalmology practices. Fam Med. 1991; 23(7):544-546. [PubMed: 1936738]

6. Kaufman HE. Adenovirus advances: new diagnostic and therapeutic options. Curr Opin Ophthalmol. 2011; 22(4):290-293. [PubMed: 21537185]

7. Hørven I. Acute conjunctivitis: a comparison of fusidic acid viscous eye drops and chloramphenicol. Acta Ophthalmol (Copenh). 1993; 71(2):165-168. [PubMed: 8333258]

8. Stenson S, Newman R, Fedukowicz H. Laboratory studies in acute conjunctivitis. Arch Ophthalmol. 1982; 100(8):1275-1277. [PubMed: 7049134]

9. Rönnerstam R, Persson K, Hansson H, Renmarker K. Prevalence of chlamydial eye infection in patients attending an eye clinic, a VD clinic, and in healthy persons. Br J Ophthalmol. 1985; 69(5): 385-388. [PubMed: 3838901]

10. Harding SP, Mallinson H, Smith JL, Clearkin LG. Adult follicular conjunctivitis and neonatal ophthalmia in a Liverpool eye hospital, 1980-1984. Eye (Lond). 1987; 1(pt 4):512-521. [PubMed: 2832220]

11. Uchio E, Takeuchi S, Itoh N, et al. Clinical and epidemiological features of acute follicular conjunctivitis with special reference to that caused by herpes simplex virus type 1 . Br J Ophthalmol. 2000; 84(9):968-972. [PubMed: 10966946]

12. Woodland RM, Darougar S, Thaker U, et al. Causes of conjunctivitis and keratoconjunctivitis in Karachi, Pakistan. Trans R Soc Trop Med Hyg. 1992; 86(3):317-320. [PubMed: 1412664]

13. Fitch CP, Rapoza PA, Owens S, et al. Epidemiology and diagnosis of acute conjunctivitis at an inner-city hospital. Ophthalmology. 1989; 96(8):1215-1220. [PubMed: 2797725]

14. Høvding G. Acute bacterial conjunctivitis. Acta Ophthalmol. 2008; 86(1):5-17. [PubMed: 17970823]

15. Bielory BP, O’Brien TP, Bielory L. Management of seasonal allergic conjunctivitis: guide to therapy. Acta Ophthalmol. 2012; 90(5):399-407. [PubMed: 22067457]

16. American Academy of Ophthalmology. Cornea/External Disease Panel. Preferred Practice Pattern Guidelines: Conjunctivitis-Limited Revision. American Academy of Ophthalmology; San Francisco, CA: 2011.

17. Mannis, MJ.; Plotnik, RD. Bacterial conjunctivitis. In: Tasman, W.; Jaeger, EA., editors. Duanes Ophthalmology on CD-ROM. Lippincott Williams \& Wilkins; 2006.

18. Cronau H, Kankanala RR, Mauger T. Diagnosis and management of red eye in primary care. Am Fam Physician. 2010; 81(2):137-144. [PubMed: 20082509]

19. Sheikh A, Hurwitz B, van Schayck CP. McLean S, Nurmatov U. Antibiotics versus placebo for acute bacterial conjunctivitis. Cochrane Database Syst Rev. 2012; 9:CD001211.

20. Montero J, Perea E. A double-blind double-dummy comparison of topical lomefloxacin $0.3 \%$ twice daily with topical gentamicin $0.3 \%$ four times daily in the treatment of acute bacterial conjunctivitis. J Clin Res. 1998; 1:29-39.

21. Papa V, Aragona P, Scuderi AC, et al. Treatment of acute bacterial conjunctivitis with topical netilmicin. Cornea. 2002; 21(1):43-47. [PubMed: 11805506] 
22. Lohr JA, Austin RD, Grossman M, Hayden GF, Knowlton GM, Dudley SM. Comparison of three topical antimicrobials for acute bacterial conjunctivitis. Pediatr Infect Dis J. 1988; 7(9):626-629. [PubMed: 2845348]

23. Huerva V, Ascaso FJ, Latre B. Tolerancia y eficacia de la tobramicina topica vs cloranfenicol en el tratamiento de las conjunctivitis bacterianas. Ciencia Pharmaceutica. 1991; 1:221-224.

24. Alves MRKJ. Evaluation of the clinical and microbiological efficacy of $0.3 \%$ ciprofloxacin drops and $0.3 \%$ tobramycin drops in the treatment of acute bacterial conjunctivitis. Rev Bras Oftalmol. $1993 ; 52: 371-377$.

25. Gallenga PE, Lobefalo L, Colangelo L, et al. Topical lomefloxacin $0.3 \%$ twice daily versus tobramycin $0.3 \%$ in acute bacterial conjunctivitis: a multicenter double-blind phase III study. Ophthalmologica. 1999; 213(4):250-257. [PubMed: 10420109]

26. Jackson WB, Low DE, Dattani D, Whitsitt PF, Leeder RG, MacDougall R. Treatment of acute bacterial conjunctivitis: $1 \%$ fusidic acid viscous drops vs $0.3 \%$ tobramycin drops. Can J Ophthalmol. 2002; 37(4):228-237. discussion 237. [PubMed: 12095096]

27. Bremond-Gignac D, Mariani-Kurkdjian P, Beresniak A, et al. Efficacy and safety of azithromycin $1.5 \%$ eye drops for purulent bacterial conjunctivitis in pediatric patients. Pediatr Infect Dis J. 2010; 29(3):222-226. [PubMed: 19935122]

28. Leibowitz HM. Antibacterial effectiveness of ciprofloxacin $0.3 \%$ ophthalmic solution in the treatment of bacterial conjunctivitis. Am J Ophthalmol. 1991; 112((4)(suppl)):29S-33S. [PubMed: 1928271]

29. Gross RD, Hoffman RO, Lindsay RN. A comparison of ciprofloxacin and tobramycin in bacterial conjunctivitis in children. Clin Pediatr (Phila). 1997; 36(8):435-444. [PubMed: 9272316]

30. Denis F, Chaumeil C, Goldschmidt P, et al. Micro-biological efficacy of 3-day treatment with azithromycin $1.5 \%$ eye-drops for purulent bacterial conjunctivitis. Eur J Ophthalmol. 2008; 18(6): 858-868. [PubMed: 18988154]

31. Silverstein BE, Allaire C, Bateman KM, et al. Efficacy and tolerability of besifloxacin ophthalmic suspension $0.6 \%$ administered twice daily for 3 days in the treatment of bacterial conjunctivitis: a multicenter, randomized, double-masked, vehicle-controlled, parallel-group study in adults and children. Clin Ther. 2011; 33(1):13-26. [PubMed: 21397770]

32. Karpecki P, Depaolis M, Hunter JA, et al. Besifloxacin ophthalmic suspension $0.6 \%$ in patients with bacterial conjunctivitis: a multicenter, prospective, randomized, double-masked, vehiclecontrolled, 5-day efficacy and safety study. Clin Ther. 2009; 31(3):514-526. [PubMed: 19393842]

33. Tepedino ME, Heller WH, Usner DW, et al. Phase III efficacy and safety study of besifloxacin ophthalmic suspension $0.6 \%$ in the treatment of bacterial conjunctivitis. Curr Med Res Opin. 2009; 25(5):1159-1169. [PubMed: 19323612]

34. McDonald MB, Protzko EE, Brunner LS, et al. Efficacy and safety of besifloxacin ophthalmic suspension $0.6 \%$ compared with moxifloxacin ophthalmic solution $0.5 \%$ for treating bacterial conjunctivitis. Ophthalmology. 2009; 116(9):1615-1623. e1. [PubMed: 19643483]

35. Gong L, Sun XH, Qiu XD, et al. Comparative research of the efficacy of the gatifloxacin and levofloxacin for bacterial conjunctivitis in human eyes [in Chinese]. Zhonghua Yan Ke Za Zhi. 2010; 46(6):525-531. [PubMed: 21055198]

36. Hwang DG, Schanzlin DJ, Rotberg MH, et al. A phase III, placebo controlled clinical trial of $0.5 \%$ levofloxacin ophthalmic solution for the treatment of bacterial conjunctivitis. Br J Ophthalmol. 2003; 87(8):1004-1009. [PubMed: 12881345]

37. Schwab IR, Friedlaender M, McCulley J, et al. A phase III clinical trial of $0.5 \%$ levofloxacin ophthalmic solution versus $0.3 \%$ ofloxacin ophthalmic solution for the treatment of bacterial conjunctivitis. Ophthalmology. 2003; 110(3):457-465. [PubMed: 12623805]

38. Zhang M, Hu Y, Chen F. Clinical investigation of $0.3 \%$ levofloxacin eyedrops on the treatment of cases with acute bacterial conjunctivitis and bacterial keratitis [in Chinese]. Yan Ke Xue Bao. 2000; 16(2):146-148. [PubMed: 12579927]

39. Gross RD, Lichtenstein SJ, Schlech BA. Early clinical and microbiological responses in the treatment of bacterial conjunctivitis with moxifloxacin ophthalmic solution $0.5 \%$ (Vigamox)using BID dosing. Todays Ther Trends. 2003; 21:227-237. 
40. Granet DB, Dorfman M, Stroman D, Cockrum P. A multicenter comparison of polymyxin B sulfate/trimethoprim ophthalmic solution and moxifloxacin in the speed of clinical efficacy for the treatment of bacterial conjunctivitis. J Pediatr Ophthalmol Strabismus. 2008; 45(6):340-349. [PubMed: 19043945]

41. Epling J, Smucny J. Bacterial conjunctivitis. Clin Evid. 2005; 2(14):756-761. [PubMed: 16620434]

42. Tabbara KF, El-Sheikh HF, Islam SM, Hammouda E. Treatment of acute bacterial conjunctivitis with topical lomefloxacin $0.3 \%$ compared to topical ofloxacin 0.3\%. Eur J Ophthalmol. 1999; 9(4):269-275. [PubMed: 10651190]

43. Abelson MB, Heller W, Shapiro AM, et al. Clinical cure of bacterial conjunctivitis with azithromycin 1\%: vehicle-controlled, double-masked clinical trial. Am J Ophthalmol. 2008; 145(6):959-965. [PubMed: 18374301]

44. Cochereau I, Meddeb-Ouertani A, Khairallah M, et al. 3-Day treatment with azithromycin 1.5\% eye drops versus 7 -day treatment with tobramycin $0.3 \%$ for purulent bacterial conjunctivitis: multicentre, randomised and controlled trial in adults and children. Br J Ophthalmol. 2007; 91(4): 465-469. [PubMed: 17050578]

45. Hallett JW, Leopold IH. Clinical trial of erythromycin ophthalmic ointment. Am J Ophthalmol. 1957; 44(4 pt 1):519-522. [PubMed: 13469938]

46. Trimethoprim-Polymyxin B Sulphate Ophthalmic Ointment Study Group. Trimethoprimpolymyxin B sulphate ophthalmic ointment versus chloramphenicol ophthalmic ointment in the treatment of bacterial conjunctivitis. J Antimicrob Chemother. 1989; 23(2):261-266. [PubMed: 2540136]

47. Workowski KA, Berman S, Centers for Disease Control and Prevention (CDC). Sexually transmitted diseases treatment guidelines, 2010. MMWR Recomm Rep. 2010; 59(RR-12):1-110. [PubMed: 21160459]

48. Sattar SA, Dimock KD, Ansari SA, Springthorpe VS. Spread of acute hemorrhagic conjunctivitis due to enterovirus-70: effect of air temperature and relative humidity on virus survival on fomites. J Med Virol. 1988; 25(3):289-296. [PubMed: 2844979]

49. O’Brien TP, Jeng BH, McDonald M, Raizman MB. Acute conjunctivitis: truth and misconceptions. Curr Med Res Opin. 2009; 25(8):1953-1961. [PubMed: 19552618]

50. Skevaki CL, Galani IE, Pararas MV, et al. Treatment of viral conjunctivitis with antiviral drugs. Drugs. 2011; 71(3):331-347. [PubMed: 21319870]

51. Katusic D, Petricek I, Mandic Z, et al. Azithromycin vs doxycycline in the treatment of inclusion conjunctivitis. Am J Ophthalmol. 2003; 135(4):447-451. [PubMed: 12654359]

52. Owen CG, Shah A, Henshaw K, et al. Topical treatments for seasonal allergic conjunctivitis: systematic review and meta-analysis of efficacy and effectiveness. Br J Gen Pract. 2004; 54(503): 451-456. [PubMed: 15186569]

53. Yaylali V, Demirlenk I, Tatlipinar S, et al. Comparative study of $0.1 \%$ olopatadine hydrochloride and $0.5 \%$ ketorolac tromethamine in the treatment of seasonal allergic conjunctivitis. Acta Ophthalmol Scand. 2003; 81(4):378-382. [PubMed: 12859265]

54. Donshik PC, Pearlman D, Pinnas J, et al. Efficacy and safety of ketorolac tromethamine $0.5 \%$ and levocabastine $0.05 \%$ : a multicenter comparison in patients with seasonal allergic conjunctivitis. Adv Ther. 2000; 17(2):94-102. [PubMed: 11010060]

55. Greiner JV, Udell IJ. A comparison of the clinical efficacy of pheniramine maleate/naphazoline hydrochloride ophthalmic solution and olopatadine hydrochloride ophthalmic solution in the conjunctival allergen challenge model. Clin Ther. 2005; 27(5):568-577. [PubMed: 15978305]

56. Greiner JV, Minno G. A placebo-controlled comparison of ketotifen fumarate and nedocromil sodium ophthalmic solutions for the prevention of ocular itching with the conjunctival allergen challenge model. Clin Ther. 2003; 25(7):1988-2005. [PubMed: 12946546]

57. Greiner JV, Michaelson C, McWhirter CL, Shams NB. Single dose of ketotifen fumarate $025 \%$ vs 2 weeks of cromolyn sodium $4 \%$ for allergic conjunctivitis. Adv Ther. 2002; 19(4):185-193. [PubMed: 12431044]

58. Butrus S, Greiner JV, Discepola M, Finegold I. Comparison of the clinical efficacy and comfort of olopatadine hydrochloride $0.1 \%$ ophthalmic solution and nedocromil sodium $2 \%$ ophthalmic 
solution in the human conjunctival allergen challenge model. Clin Ther. 2000; 22(12):1462-1472. [PubMed: 11192137]

59. Deschenes J, Discepola M, Abelson M. Comparative evaluation of olopatadine ophthalmic solution $(0.1 \%)$ versus ketorolac ophthalmic solution $(0.5 \%)$ using the provocative antigen challenge model. Acta Ophthalmol Scand Suppl. 1999; (228):47-52. [PubMed: 10337433]

60. Gibbons RJ, Smith S, Antman E, American College of Cardiology; American Heart Association. American College of Cardiology/American Heart Association clinical practice guidelines, part I. Circulation. 2003; 107(23):2979-2986. [PubMed: 12814985]

61. Rietveld RP, van Weert HC, ter Riet G, Bindels PJ. Diagnostic impact of signs and symptoms in acute infectious conjunctivitis: systematic literature search. BMJ. 2003; 327(7418):789. [PubMed: 14525879]

62. Yannof, J.; Duker, JS., editors. Ophthalmology. 2nd ed. Mosby; Spain: 2004. Disorders of the conjunctiva and limbus; p. 397-412.

63. Morrow GL, Abbott RL. Conjunctivitis. Am Fam Physician. 1998; 57(4):735-746. [PubMed: 9490996]

64. Rietveld RP, ter Riet G, Bindels PJ, Sloos JH, van Weert HC. Predicting bacterial cause in infectious conjunctivitis. BMJ. 2004; 329(7459):206-210. [PubMed: 15201195]

65. Tarabishy AB, Jeng BH. Bacterial conjunctivitis: a review for internists. Cleve Clin J Med. 2008; 75(7):507-512. [PubMed: 18646586]

66. Sambursky R, Tauber S, Schirra F, et al. The RPS adeno detector for diagnosing adenoviral conjunctivitis. Ophthalmology. 2006; 113(10):1758-1764. [PubMed: 17011956]

67. Epling J. Bacterial conjunctivitis. Clin Evid (Online). 2010; 2010

68. Mahmood AR, Narang AT. Diagnosis and management of the acute red eye. Emerg Med Clin North Am. 2008; 26(1):35-55. vi. [PubMed: 18249256]

69. Azar MJ, Dhaliwal DK, Bower KS, et al. Possible consequences of shaking hands with your patients with epidemic keratoconjunctivitis. Am J Ophthalmol. 1996; 121(6):711-712. [PubMed: 8644817]

70. Warren D, Nelson KE, Farrar JA, et al. A large outbreak of epidemic keratoconjunctivitis: problems in controlling nosocomial spread. J Infect Dis. 1989; 160(6):938-943. [PubMed: 2555421]

71. Wilhelmus KR. Diagnosis and management of herpes simplex stromal keratitis. Cornea. 1987; 6(4):286-291. [PubMed: 3319411]

72. Puri LR, Shrestha GB, Shah DN, Chaudhary M, Thakur A. Ocular manifestations in herpes zoster ophthalmicus. Nepal J Ophthalmol. 2011; 3(2):165-171. [PubMed: 21876592]

73. Sy A, McLeod SD, Cohen EJ, et al. Practice patterns and opinions in the management of recurrent or chronic herpes zoster ophthalmicus. Cornea. 2012; 31(7):786-790. [PubMed: 22269677]

74. Sheikh A, Hurwitz B. Topical antibiotics for acute bacterial conjunctivitis: Cochrane systematic review and meta-analysis update. Br J Gen Pract. 2005; 55(521):962-964. [PubMed: 16378567]

75. Szaflik J, Szaflik JP, Kaminska A, Levofloxacin Bacterial Conjunctivitis Dosage Study Group. Clinical and microbiological efficacy of levofloxacin administered three times a day for the treatment of bacterial conjunctivitis. Eur J Ophthalmol. 2009; 19(1):1-9. [PubMed: 19123142]

76. Shanmuganathan VA, Armstrong M, Buller A, Tullo AB. External ocular infections due to methicillin-resistant Staphylococcus aureus (MRSA). Eye (Lond). 2005; 19(3):284-291. [PubMed: 15375372]

77. Freidlin J, Acharya N, Lietman TM, et al. Spectrum of eye disease caused by methicillin-resistant Staphylococcus aureus. Am J Ophthalmol. 2007; 144(2):313-315. [PubMed: 17659970]

78. Postema EJ, Remeijer L, van der Meijden WI. Epidemiology of genital chlamydial infections in patients with chlamydial conjunctivitis. Genitourin Med. 1996; 72(3):203-205. [PubMed: 8707324]

79. Kumaresan JA, Mecaskey JW. The global elimination of blinding trachoma: progress and promise. Am J Trop Med Hyg. 2003; 69((5)(suppl)):24-28. [PubMed: 14692677]

80. Avery, RK.; Baker, AS. Albert and Jakobiec's Principle and Practice of Ophthalmology. 3rd ed. Saunders Elsevier; Philadelphia, PA: 2008. Chlamydial disease; p. 4791-4801. 
81. Rosario N, Bielory L. Epidemiology of allergic conjunctivitis. Curr Opin Allergy Clin Immunol. 2011; 11(5):471-476. [PubMed: 21785348]

82. Bielory L. Allergic conjunctivitis: the evolution of therapeutic options. Allergy Asthma Proc. 2012; 33(2):129-139. [PubMed: 22525389]

83. Baudouin C. Allergic reaction to topical eyedrops. Curr Opin Allergy Clin Immunol. 2005; 5(5): 459-463. [PubMed: 16131924]

84. Newburger JW, Takahashi M, Gerber MA, et al. Diagnosis, treatment, and long-term management of Kawasaki disease: a statement for health professionals from the Committee on Rheumatic Fever, Endocarditis, and Kawasaki Disease, Council on Cardiovascular Disease in the Young, American Heart Association. Pediatrics. 2004; 114(6):1708-1733. [PubMed: 15574639]

85. Gregory DG. The ophthalmologic management of acute Stevens-Johnson syndrome. Ocul Surf. 2008; 6(2):87-95. [PubMed: 18418506]

86. Miller NR. Diagnosis and management of dural carotid-cavernous sinus fistulas. Neurosurg Focus. 2007; 23(5):13. 

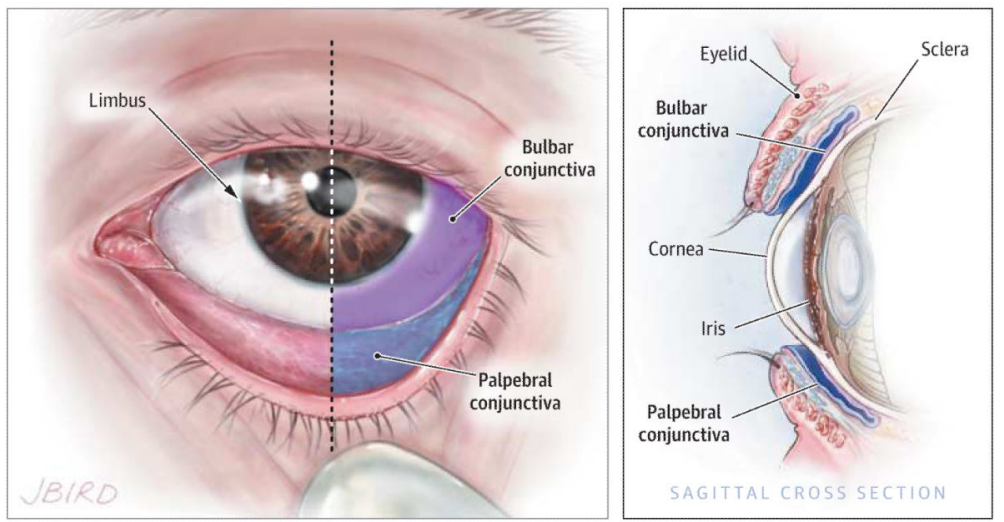

Figure 1. Normal Conjunctival Anatomy

The conjunctiva is a thin membrane covering the sclera (bulbar conjunctiva, labeled with purple) and the inside of the eyelids (palpebral conjunctiva, labeled with blue). 


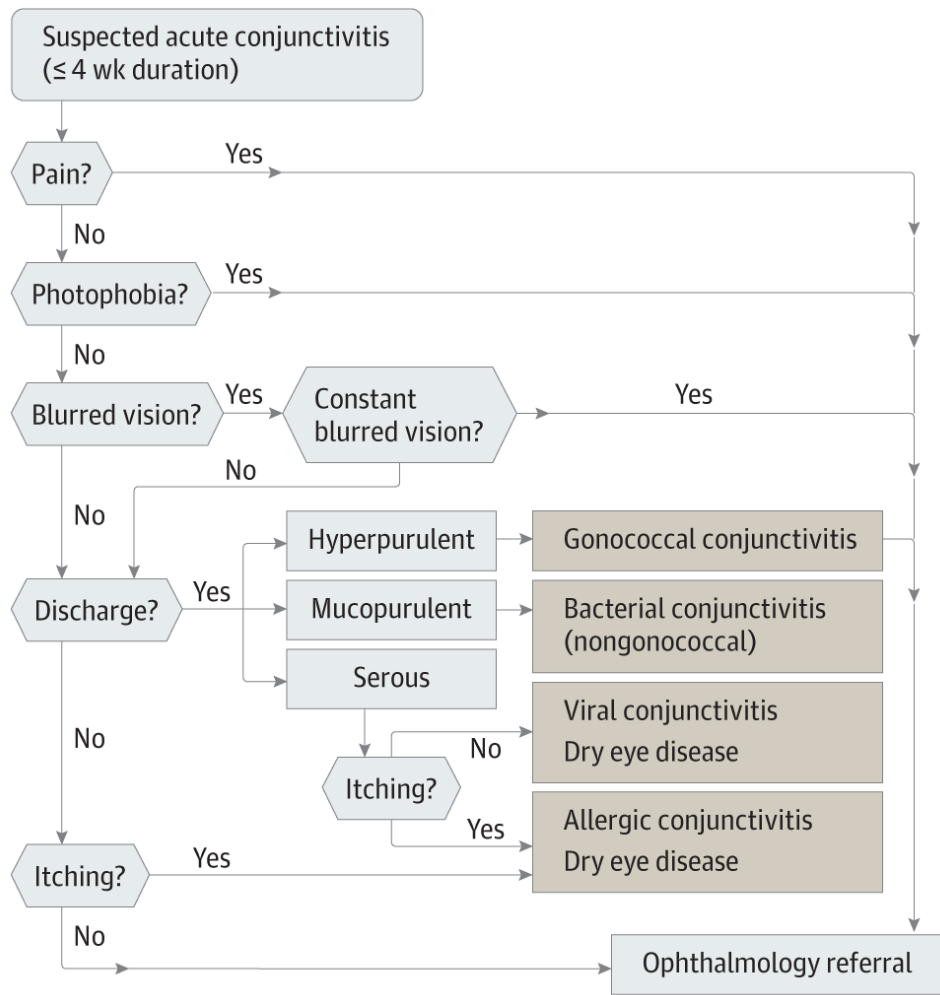

Figure 2. Suggested Algorithm for Clinical Approach to Suspected Acute Conjunctivitis 

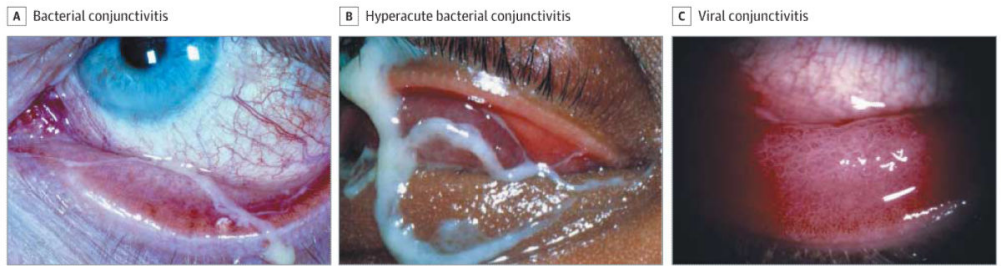

Figure 3. Characteristic Appearance of Bacterial and Viral Conjunctivitis

A, Bacterial conjunctivitis characterized by mucopurulent discharge and conjunctival hyperemia. B, Severe purulent discharge seen in hyperacute bacterial conjunctivitis secondary to gonorrhea. $\mathrm{C}$, Intensely hyperemic response with thin, watery discharge characteristic of viral conjunctivitis. Images reproduced with permission: () 2013 American Academy of Ophthalmology. 
Table 1

\section{Selected Nonconjunctivitis Causes of Red Eye ${ }^{a}$}

\begin{tabular}{|c|c|c|}
\hline Differential Diagnosis & Symptoms & Penlight Examination Findings \\
\hline Dry eye disease & $\begin{array}{l}\text { Burning and foreign-body sensation. Symptoms are } \\
\text { usu- } \\
\text { ally transient, worse with prolonged reading or } \\
\text { watching } \\
\text { television because of decreased blinking. Symptoms } \\
\text { are } \\
\text { worse in dry, cold, and windy environments } \\
\text { because of } \\
\text { increased evaporation. }\end{array}$ & Bilateral redness \\
\hline Blepharitis & Similar to dry eyes & Redness greater at the margins of eyelids \\
\hline Uveitis & $\begin{array}{l}\text { Photophobia, pain, blurred vision. Symptoms are } \\
\text { usually } \\
\text { bilateral. }\end{array}$ & $\begin{array}{l}\text { Decreased vision, poorly reacting pupils, constant eye } \\
\text { pain radiating to temple and brow. Redness, } \\
\text { severe photophobia, presence of inflammatory cells in } \\
\text { the anterior chamber. }\end{array}$ \\
\hline Angle closure glaucoma & $\begin{array}{l}\text { Headaches, nausea, vomiting, ocular pain, } \\
\text { decreased } \\
\text { vision, light sensitivity, and seeing haloes around } \\
\text { lights. } \\
\text { Symptoms are usually unilateral. }\end{array}$ & $\begin{array}{l}\text { Firm eye on palpation, ocular redness with limbal injec- } \\
\text { tion. Appearance of a hazy/steamy cornea, moderately } \\
\text { dilated pupils that are unreactive to light. }\end{array}$ \\
\hline Carotid cavernous fistula & Chronic red eye; may have a history of head trauma & $\begin{array}{l}\text { Dilated tortuous vessels (corkscrew vessels), bruits on } \\
\text { auscultation with a stethoscope }\end{array}$ \\
\hline Endophthalmitis & $\begin{array}{l}\text { Severe pain, photophobia, may have a history of eye } \\
\text { sur- } \\
\text { gery or ocular trauma }\end{array}$ & $\begin{array}{l}\text { Redness, pus in the anterior chamber, and } \\
\text { photophobia }\end{array}$ \\
\hline Cellulitis & Pain, double vision, and fullness & $\begin{array}{l}\text { Redness and swelling of lids, may have restriction of the } \\
\text { eye movements, may have a history of preceding sinus- } \\
\text { itis (usually ethmoiditis) }\end{array}$ \\
\hline Anterior segment tumors & Variable & Abnormal growth inside or on the surface of the eye \\
\hline Scleritis & Decreased vision, moderate to severe pain & Redness, bluish sclera hue \\
\hline Subconjunctival hemorrhage & $\begin{array}{l}\text { May have foreign-body sensation and tearing or be } \\
\text { asymptomatic }\end{array}$ & Blood under the conjunctival membrane \\
\hline
\end{tabular}

${ }^{a}$ Data are from Cronau et al ${ }^{18}$ and Leibowitz. ${ }^{1}$ The examination can be done by shining a penlight in the patient's affected eye(s) 
Table 2

Ophthalmic Therapies for Conjunctivitis

\begin{tabular}{|c|c|c|c|c|c|}
\hline Category & Epidemiology & $\begin{array}{l}\text { Type of } \\
\text { Discharge }\end{array}$ & Cause & Treatment & $\begin{array}{l}\text { Level of } \\
\text { Evidence } \\
\text { for } \\
\text { Treatment }\end{array}$ \\
\hline \multirow{17}{*}{$\begin{array}{l}\text { Acute bacterial } \\
\text { conjunctivitis }\end{array}$} & \multirow{17}{*}{$\begin{array}{l}135 \text { case per } 10000 \\
\text { population in } \mathrm{US}^{3} \\
18.3 \%-57 \% \text { of all acute } \\
\text { conjunctivitis }^{7-9,12,13}\end{array}$} & \multirow[t]{17}{*}{ Mucopurulent } & \multirow{17}{*}{$\begin{array}{l}S \text { aureus, } \\
\text { S epidermidis, } H \\
\text { influenzae, } \\
\text { S pneumoniae, } \\
S \text { viridans, Moraxella spp }\end{array}$} & \multicolumn{2}{|l|}{ Aminoglycosides } \\
\hline & & & & $\begin{array}{l}\text { Gentamicin } \\
\text { Ointment: } 4 \times / \mathrm{d} \text { for } 1 \mathrm{wk} \\
\text { Solution: } 1-2 \text { drops } 4 \times / \mathrm{d} \text { for } 1 \mathrm{wk}\end{array}$ & $\mathrm{B}^{20-22}$ \\
\hline & & & & $\begin{array}{l}\text { Tobramycin ointment: } 3 \times / \mathrm{d} \text { for } 1 \\
\text { wk }\end{array}$ & $A^{23-30}$ \\
\hline & & & & \multicolumn{2}{|l|}{ Fluoroquinolones } \\
\hline & & & & $\begin{array}{l}\text { Besifloxacin: } 1 \text { drop } 3 \times / d \text { for } 1 \\
\text { wk }\end{array}$ & $\mathrm{A}^{31-34}$ \\
\hline & & & & $\begin{array}{l}\text { Ciprofloxacin ointment: } 3 \times / \mathrm{d} \text { for } \\
1 \mathrm{wk} \\
\text { Solution: } 1-2 \text { drops } 4 \times / \mathrm{d} \text { for } 1 \mathrm{wk}\end{array}$ & $\mathrm{A}^{24,28,29}$ \\
\hline & & & & Gatifloxacin: $3 \times / \mathrm{d}$ for 1 week & $\mathrm{B}^{35}$ \\
\hline & & & & $\begin{array}{l}\text { Levofloxacin: } 1-2 \text { drops } 4 \times / \mathrm{d} \text { for } \\
1 \mathrm{wk}\end{array}$ & $\mathrm{B}^{36-38}$ \\
\hline & & & & Moxifloxacin: $3 \times / \mathrm{d}$ for $1 \mathrm{wk}$ & $\mathrm{A}^{34,39,40}$ \\
\hline & & & & $\begin{array}{l}\text { Ofloxacin: } 1-2 \text { drops } 4 \times / \text { d for } 1 \\
\text { wk }\end{array}$ & $\mathrm{A}^{37,38,41,42}$ \\
\hline & & & & \multicolumn{2}{|l|}{ Macrolides } \\
\hline & & & & $\begin{array}{l}\text { Azithromycin: } 2 \times / \mathrm{d} \text { for } 2 \mathrm{~d} \text {; then } \\
1 \text { drop } \\
\text { daily for } 5 \mathrm{~d}\end{array}$ & $\mathrm{~A}^{27,30,43,44}$ \\
\hline & & & & Erythromycin: $4 \times / \mathrm{d}$ for $1 \mathrm{wk}$ & $\mathrm{B}^{45}$ \\
\hline & & & & \multicolumn{2}{|l|}{ Sulfonamides } \\
\hline & & & & $\begin{array}{l}\text { Sulfacetamide ointment: } 4 \times / \mathrm{d} \text { and } \\
\text { at } \\
\text { bedtime for } 1 \mathrm{wk} \\
\text { Solution: } 1-2 \text { drops every } 2-3 \mathrm{~h} \text { for } \\
1 \mathrm{wk}\end{array}$ & $\mathrm{B}^{22}$ \\
\hline & & & & \multicolumn{2}{|l|}{ Combination drops } \\
\hline & & & & $\begin{array}{l}\text { Trimethoprim/polymyxin B: } 1 \text { or } 2 \\
\text { drops } \\
4 \times / \mathrm{d} \text { for } 1 \mathrm{wk}\end{array}$ & $\mathrm{A}^{22,40,46}$ \\
\hline \multirow{3}{*}{$\begin{array}{l}\text { Hyperacute } \\
\text { bacterial } \\
\text { conjunctivitis } \\
\text { in adults }\end{array}$} & \multirow[t]{3}{*}{ NA } & \multirow[t]{3}{*}{ Purulent } & \multirow[t]{3}{*}{ Neisseria gonorrhoeae } & Ceftriaxone: $1 \mathrm{~g}$ IMonce & $C^{16,47}$ \\
\hline & & & & Lavage of the infected eye & $\mathrm{C}^{16}$ \\
\hline & & & & $\begin{array}{l}\text { Dual therapy to cover chlamydia is } \\
\text { indicated }\end{array}$ & $\mathrm{C}^{48}$ \\
\hline $\begin{array}{l}\text { Viral } \\
\text { conjunctivitis }\end{array}$ & $\begin{array}{l}9 \%-80.3 \% \text { of all acute } \\
\text { conjunctivitis }^{8-13}\end{array}$ & Serous & $\begin{array}{l}\text { Up to } 65 \% \text { are due to } \\
\text { adenovirus strains } 49\end{array}$ & $\begin{array}{l}\text { Cold compress } \\
\text { Artificial tears } \\
\text { Antihistamines }\end{array}$ & $\mathrm{C}^{16,50}$ \\
\hline \multirow[t]{2}{*}{$\begin{array}{l}\text { Herpes zoster } \\
\text { virus }\end{array}$} & \multirow[t]{2}{*}{ NA } & \multirow[t]{2}{*}{ Variable } & \multirow[t]{2}{*}{ Herpes zoster virus } & $\begin{array}{l}\text { Oral acyclovir } 800 \mathrm{mg}: 5 \times / \mathrm{d} \text { for } \\
7-10 \mathrm{~d}\end{array}$ & $\mathrm{C}^{16}$ \\
\hline & & & & $\begin{array}{l}\text { Oral famciclovir } 500 \mathrm{mg}: 3 \times / \mathrm{d} \text { for } \\
7-10 \mathrm{~d}\end{array}$ & $\mathrm{C}^{16}$ \\
\hline
\end{tabular}




\begin{tabular}{|c|c|c|c|c|c|}
\hline Category & Epidemiology & $\begin{array}{l}\text { Type of } \\
\text { Discharge }\end{array}$ & Cause & Treatment & $\begin{array}{l}\text { Level of } \\
\text { Evidence } \\
\text { for } \\
\text { Treatment }\end{array}$ \\
\hline & & & & $\begin{array}{l}\text { Oral valacyclovir } 1000 \mathrm{mg}: 3 \times / \mathrm{d} \\
\text { for } 7-10 \mathrm{~d}\end{array}$ & $\mathrm{C}^{16}$ \\
\hline \multirow{3}{*}{$\begin{array}{l}\text { Herpes simplex } \\
\text { virus }\end{array}$} & \multirow{3}{*}{$\begin{array}{l}\text { 1.3-4.8 of all acute } \\
\text { conjunctivitis }{ }^{9-12}\end{array}$} & \multirow[t]{3}{*}{ Variable } & \multirow[t]{3}{*}{ Herpes simplex virus } & Topical acyclovir: 1 drop $9 \times / \mathrm{d}$ & $\mathrm{C}^{16}$ \\
\hline & & & & $\begin{array}{l}\text { Oral acyclovir } 400 \mathrm{mg}: 5 \times / \mathrm{d} \text { for } \\
7-10 \mathrm{~d}\end{array}$ & $\mathrm{C}^{16}$ \\
\hline & & & & $\begin{array}{l}\text { Oral valacyclovir } 500 \mathrm{mg}: 3 \times / \mathrm{d} \\
\text { for } 7-10 \mathrm{~d}\end{array}$ & $\mathrm{C}^{16}$ \\
\hline \multirow{2}{*}{$\begin{array}{l}\text { Adult inclusion } \\
\text { conjunctivitis }\end{array}$} & \multirow{2}{*}{$\begin{array}{l}1.8 \%-5.6 \% \text { of all acute } \\
\text { conjunctivitis }^{5,8-11}\end{array}$} & \multirow[t]{2}{*}{ Variable } & \multirow[t]{2}{*}{ Chlamydia trachomatis } & Azithromycin $1 \mathrm{~g}$ : orally once & $\mathrm{B}^{16,51}$ \\
\hline & & & & $\begin{array}{l}\text { Doxycycline } 100 \mathrm{mg} \text { : orally } 2 \times / \mathrm{d} \\
\text { for } 7 \mathrm{~d}\end{array}$ & $\mathrm{~B}^{16,51}$ \\
\hline \multirow{14}{*}{$\begin{array}{l}\text { Allergic } \\
\text { conjunctivitis }\end{array}$} & \multirow{14}{*}{$\begin{array}{l}90 \% \text { of all allergic } \\
\text { conjunctivitis }{ }^{15} ; \\
\text { up to } 40 \% \text { of } \\
\text { population may be } \\
\text { affected }^{15}\end{array}$} & \multirow{14}{*}{$\begin{array}{l}\text { Serous or } \\
\text { mucoid }\end{array}$} & \multirow[t]{14}{*}{ Pollens } & Topical antihistamines & \\
\hline & & & & Azelastine $0.05 \%: 1$ drop $2 \times / \mathrm{d}$ & $\mathrm{A}^{52}$ \\
\hline & & & & Emedastine $0.05 \%: 1$ drop $4 \times / \mathrm{d}$ & $\mathrm{A}^{52}$ \\
\hline & & & & Topical mast cell inhibitors & \\
\hline & & & & $\begin{array}{l}\text { Cromolyn sodium 4\%: 1-2 drops } \\
\text { every } 4-6 \mathrm{~h}\end{array}$ & $\mathrm{~A}^{52}$ \\
\hline & & & & $\begin{array}{l}\text { Lodoxamide } 0.1 \%: 1-2 \text { drops } 4 \\
\times / \mathrm{d}\end{array}$ & $\mathrm{A}^{52}$ \\
\hline & & & & Nedocromil $2 \%: 1-2$ drops $2 \times / \mathrm{d}$ & $\mathrm{A}^{52}$ \\
\hline & & & & NSAIDs & \\
\hline & & & & Ketorolac: 1 drop $4 \times / d$ & $\mathrm{~B}^{53,54}$ \\
\hline & & & & Vasoconstrictor/antihistamine & \\
\hline & & & & $\begin{array}{l}\text { Naphazoline/pheniramine: } 1-2 \\
\text { drops up to } \\
4 \times / d\end{array}$ & $\mathrm{~B}^{55}$ \\
\hline & & & & Combination drops & \\
\hline & & & & Ketotifen $0.025 \%: 1$ drop $2-3 \times / d$ & $\mathrm{~A}^{56,57}$ \\
\hline & & & & Olopatadine $0.1 \%$ : 1 drop $2 \times / d$ & $\mathrm{~A}^{58,59}$ \\
\hline
\end{tabular}

Abbreviations: IM, intramuscularly; NA, not available; NSAIDs, nonsteroidal anti-inflammatory drugs. 
Table 3

Evidence-Based Recommendations in Conjunctivitis

\begin{tabular}{ll}
\hline Recommendation & $\begin{array}{l}\text { Level of } \\
\text { Evidence }\end{array}$ \\
\hline $\begin{array}{l}\text { Topical antibiotics are effective in reducing the duration of } \\
\text { conjunctivitis. }\end{array}$ & $\mathrm{A}^{19}$ \\
\hline $\begin{array}{l}\text { Observation is reasonable in most cases of bacterial conjunctivitis } \\
\text { suspected or confirmed) because they often resolve spontane- }\end{array}$ & $\mathrm{A}^{41}$ \\
ously and no treatment is necessary. & $\mathrm{A}^{19,41}$ \\
\hline $\begin{array}{l}\text { It is reasonable to use any broad-spectrum antibiotics for treating } \\
\text { bacterial conjunctivitis. }\end{array}$ & $\mathrm{A}^{52}$ \\
\hline $\begin{array}{l}\text { In allergic conjunctivitis, use of topical antihistamines and mast } \\
\text { cell stabilizers is recommended. }\end{array}$ & $\mathrm{C}^{16}$ \\
\hline $\begin{array}{l}\text { Good hand hygiene can be used to decrease the spread of acute } \\
\text { viral conjunctivitis. }\end{array}$ & $\mathrm{C}^{16}$ \\
\hline $\begin{array}{l}\text { Bacterial cultures can be useful in cases of severely purulent } \\
\text { conjunctivitis or cases that are recalcitrant to therapy. }\end{array}$ & $\mathrm{C}^{16}$ \\
\hline $\begin{array}{l}\text { It may be helpful to treat viral conjunctivitis with artificial tears, } \\
\text { topical antihistamines, or cold compresses. }\end{array}$ & $\mathrm{C}^{65}$ \\
\hline \begin{tabular}{l} 
Topical steroids are not recommended for bacterial conjunctivitis. \\
\hline
\end{tabular}
\end{tabular}

